\title{
Karakteristik Sosial Ekonomi dan Kesehatan Maternal
}

\author{
Socioeconomic Characteristics and Maternal Health
}

\section{Rindang Ekawati}

Balai Pelatihan dan Pengembangan Perwakilan Badan Kependudukan dan Keluarga Berencana Nasional Provinsi Jawa Barat

\begin{abstract}
Abstrak
Kesehatan maternal yang tergolong tinggi di Indonesia merupakan indikator keberhasilan pembangunan pada Millenium Development Goals yang terus diupayakan untuk diperbaiki. Penelitian ini bertujuan mengetahui hubungan antara karakteristik sosial, demografi, dan ekonomi dengan tingkat kesehatan ibu. Penelitian yang menggunakan sumber data sekunder Survei Demografi Kesehatan di Jawa Barat yang mencakup 86 blok sensus yang meliputi 2.150 rumah tangga meliputi 1.100 rumah tangga di perkotaan dan 1.050 rumah tangga di pedesaan. Jumlah sampel terpilih adalah 1.720 wanita pernah kawin berumur $15-49$ tahun. Analisis data dilakukan secara deskriptif analitik dan uji kai kuadrat.Terdapat hubungan signifikan antara umur ibu, pendidikan ibu, dan indeks kesejahteraan dengan pemilihan tenaga penolong persalinan oleh tenaga kesehatan. Juga terdapat hubungan yang signifikan antara kesertaan dalam program Keluarga Berencana dengan umur ibu, pendidikan, dan indeks kesejahteraan. Tidak ada hubungan yang signifikan antara kesertaan ber-KB dengan daerah tempat tinggal dan jumlah anak yang masih hidup. Terdapat hubungan signifikan antara tempat persalinan dengan daerah tempat tinggal, tingkat pendidikan ibu, indeks kesejahtaraan, serta jumlah anak yang masih hidup.

Kata kunci: Sosial ekonomi, kesehatan maternal, pemakaian kontrasepsi
\end{abstract}

\footnotetext{
Abstract

High level of maternal health in Indonesia is one of Millenium Development Goal's indicators, so that the government continually put this variable as priority to be improved. This study attempted to know the relationship between social, demographic, and economic characteristics with maternal health. Data source is obtained from Demographic and Health Survey 2007, West Java Province, which included 86 census blocks, 2.150 households. Among 2.150 households, 1.100 live in urban area, while 1.050 in rural area. Total selected sample is 1.720 ever married women aged between 15 -49 years old. This research using chi-square test to observed whether there is a significant relationship between age, level of education, and wealth
}

indexes with birth attendance. There is also significant relationship between contraceptive use with women's age, level of education, and level of wealth indexes. While, there is no significant relationship between contraceptive use with place of residence and number of children alive. According to the result, there is significant relationship beetween place of birth delivery with place of residence, level of education, wealth indexes, and number of children alive.

Key words: Socioeconomic, maternal health, contraceptive use

\section{Pendahuluan}

Di Indonesia, program kesehatan ibu menargetkan setiap ibu hamil melakukan paling sedikit 4 kali kunjungan periksa hamil, masing-masing sekali pada trimester pertama dan kedua serta 2 kali pada trimester ketiga. ${ }^{1}$ Setiap ibu hamil diajurkan diperiksa tinggi dan berat badan, tekanan darah, mendapat pil zat besi, imunisasi tetanus toksoid (TT), dan pemeriksaan tinggi fundus. ${ }^{1}$ Setiap kunjungan pemeriksaan kehamilan, ibu harus dijelaskan tentang tanda-tanda komplikasi kehamilan, ditimbang berat badan serta diperiksa darah dan urin.

Angka persalinan di rumah (54\%) tergolong tinggi berhubungan dengan sikap atau perilaku ibu hamil. Beberapa faktor yang berpengaruh pada persalinan di rumah meliputi rasa nyaman di lingkungan keluarga, jarak ke fasilitas kesehatan yang jauh dan sulit, serta faktor sosial ekonomi. Sebagian besar ibu yang melahirkan

Alamat Korespondensi: Rindang Ekawati, Balatbang Perwakilan BKKBN Provinsi Jawa Barat, Jl. Sederhana No. 1 Bandung 40122, Hp. 081220376818 , e-mail: rindeka_1303@yahoo.co.id 
anak di rumah bermukim di daerah pedesaan dengan tingkat pendidikan sekolah dasar (SD) atau lebih rendah. Informasi ini dapat menjadi bahan pertimbangan apabila dilakukan intervensi berupa sosialisasi tentang tempat persalinan yang sehat dan aman. Wanita di wilayah perkotaan, berpendidikan relatif tinggi, dan level sosial ekonomi tinggi lebih memilih bersalin di fasilitas kesehatan. Jumlah anak masih hidup juga menunjukkan hubungan yang bermakna dengan persalinan di fasilitas kesehatan.

Di Jawa Barat, sekitar 10\% kebutuhan program Keluarga Berencana (KB) tidak terpenuhi dan hanya sekitar $61 \%$ pasangan usia subur (PUS) yang menggunakan alat kontrasepsi. ${ }^{2-4}$ Apabila tidak dilakukan berbagai upaya antisipatif, layak diduga bahwa hal tersebut akan berdampak buruk terhadap pembangunan sumber daya manusia. Apabila terus diabaikan dan tidak dilakukan perbaikan, kemungkinan hal tersebut akan berpengaruh terhadap peningkatan fertilitas penduduk. Tentu saja hal tersebut tidak diinginkan karena akan meningkatkan beban keluarga dan berpengaruh negatif terhadap kesehatan ibu dan anak.

Model analisis fertilitas Ronald Freedman menjelaskan bahwa pemakaian alat kontrasepsi dapat memengaruhi fertilitas secara langsung. Semakin tinggi pemakaian alat kontrasepsi, semakin besar penurunan tingkat fertilitas. ${ }^{5}$ Selanjutnya, program KB mampu menurunkan fertilitas dengan atau tanpa kemajuan pembangunan sosial ekonomi. Pemakaian alat kontrasepsi biasanya lebih ditekankan pada karakteristik sosial ekonomi individu dan kontak dengan program KB. Keikutsertaan seseorang dalam program KB dengan memperhatikan faktor-faktor demografi, sosial, ekonomi, infrastruktur, dan input program. ${ }^{6}$ Kajian penggunaan alat kontrasepsi diperlukan untuk mengetahui kontribusi terhadap penurunan tingkat kelahiran serta implikasi di era otonomi daerah di Indonesia, khususnya di Jawa Barat. Penelitian ini bertujuan untuk mengetahui hubungan antara karakteristik sosial, demografi, dan ekonomi dengan tingkat kesehatan ibu.

\section{Metode}

Desain studi yang digunakan pada penelitian adalah cross sectional yang mengumpulkan variabel dependen dan independen secara bersamaan sehingga tidak ada masa pengamatan. Penelitian menggunakan sumber data sekunder, survei demografi kesehatan di Jawa Barat yang mencakup 86 blok sensus meliputi 2.150 rumah tangga, 1.100 rumah tangga di perkotaan dan 1.050 rumah tangga di pedesaan. Analisis data dilakukan secara deskriptif dan analisis statistik inferensi dengan menggunakan uji chi square. Variabel terkait kesehatan maternal yang diteliti meliputi pertolongan persalinan, prevalensi pemakaian kontrasepsi, pemeriksaan antenatal, serta kebu- tuhan KB yang tidak terpenuhi.

\section{Hasil}

\section{Penolong dan Tempat Persalinan}

Proporsi anak yang dilahirkan di rumah tergolong tinggi (55\%), kelompok ibu berumur $<20$ tahun dan $>$ 35 tahun relatif lebih banyak yang bersalin di rumah (67\% dan 58\%) dibandingkan ibu yang berumur 20 34 tahun $(52 \%)$. Semakin tinggi varitas kelahiran maka semakin tinggi persalinan di rumah, anak urutan kelahiran $1(50 \%)$; urutan $2-3(53 \%)$; urutan $4-5(69 \%)$; dan urutan 6 ke atas $(81 \%)$. Semakin tinggi pendidikan ibu maka semakin tinggi pula pemanfaatan fasilitas persalinan. Ibu yang tidak bersekolah tidak ada yang melahirkan di fasilitas pelayanan kesehatan. Sementara, proporsi ibu yang melahirkan di rumah tidak tamat SD sebanyak $17 \%$, tamat SD sebanyak $26 \%$, tidak tamat SMTA sebanyak $52 \%$, serta tamat SMTA ke atas sebanyak $73 \%$. Berdasarkan frekuensi pemeriksaan kehamilan, frekuensi $0-3$ kali melahirkan di fasilitas kesehatan $(35 \%)$ dan frekuensi 4 kali atau lebih $(51 \%)$. Semakin tinggi indeks kuintil kekayaan, semakin banyak yang melahirkan di fasilitas kesehatan. Proporsi persalinan di fasilitas kesehatan dengan indeks kuintil terbawah $(13 \%)$, menengah bawah $(23 \%)$, menengah $(34 \%)$, menengah atas $(46 \%)$ serta teratas $(73 \%)$.

Persalinan yang ditolong oleh tenaga profesional bervariasi berdasarkan umur ibu, terbanyak pada ibu yang berumur $20-34$ tahun (72\%). Proporsi persalinan yang ditolong oleh tenaga profesional semakin menurun berdasarkan peningkatan urutan kelahiran, urutan pertama $(74 \%)$ lebih besar dibandingkan keenam atau lebih $(36 \%)$. Dukun bayi masih berperan menolong persalinan $(30 \%)$, terutama pada wanita usia di bawah 20 tahun (47\%), urutan kelahiran keenam atau lebih (57\%), wanita di pedesaan $(41 \%)$, berpendidikan rendah $(64 \%-$ $66 \%)$, dan berada pada indeks kekayaan kuintil terbawah $(78 \%)$. Persalinan dengan bedah caesar meningkat bersamaan dengan peningkatan umur ibu, ibu berumur 20 tahun (5\%), dan $35-49$ tahun (7\%). Persalinan bedah caesar di perkotaan (9\%) lebih tinggi dibandingkan pedesaan $(4 \%$ ) yakni pada ibu berpendidikan SMTA atau lebih $(10 \%)$ dan ibu dengan indeks kekayaan kuintil teratas $(14 \%)$ (Lihat Tabel 1).

Di Jawa Barat, secara keseluruhan sekitar 70\% persalinan ditolong oleh tenaga profesional, persalinan terbanyak secara berurutan ditolong oleh bidan (56\%), dukun bayi (30\%), dan dokter ahli kandungan (11\%). Angka tersebut meningkat sesuai dengan peningkatan umur ibu, pendidikan ibu, dan indeks kekayaan kuintil, tetapi menurun sesuai dengan peningkatan urutan kelahiran anak. Angka persalinan profesional lebih tinggi di perkotaan $(79 \%)$ dibandingkan pedesaan $(57 \%)$. Penelitian menemukan hubungan yang signifikan antara 
Tabel 1. Analisis Bivariat Faktor Sosial Demografi dengan Tempat Persalinan

\begin{tabular}{|c|c|c|c|c|c|}
\hline \multirow{2}{*}{ Variabel } & \multirow{2}{*}{ Kategori } & \multicolumn{2}{|c|}{ Tempat Persalinan } & \multirow{2}{*}{ Jumlah } & \multirow{2}{*}{ Nilai $p$} \\
\hline & & Yankes & NonYankes & & \\
\hline \multirow[t]{2}{*}{ Umur } & $15-29$ tahun & $531(51 \%)$ & $657(52 \%)$ & 1.188 & 0,626 \\
\hline & $30-49$ tahun & $521(50 \%)$ & $618(49 \%)$ & 1.140 & \\
\hline \multirow[t]{2}{*}{ Daerah tempat tinggal } & Perkotaan & $763(73 \%)$ & $399(31 \%)$ & 1.162 & 0,000 \\
\hline & Pedesaan & $289(28 \%)$ & $877(69 \%)$ & 1.166 & \\
\hline \multirow[t]{2}{*}{ Pendidikan } & TS - TT SLTP & $561(53 \%)$ & $1.107(87 \%)$ & 1.668 & 0,000 \\
\hline & Tamat SLTP ke atas & $491(47 \%)$ & $169(13 \%)$ & 660 & \\
\hline \multirow[t]{2}{*}{ Indeks kesejahteraan } & Termiskin - menengah & $115(11 \%)$ & $461(36 \%)$ & 576 & 0,000 \\
\hline & Kaya - terkaya & $937(89 \%)$ & $815(64 \%)$ & 1.752 & \\
\hline \multirow[t]{2}{*}{ Anak masih hidup } & $0-2$ & $795(76 \%)$ & $812(64 \%)$ & 1.607 & 0,000 \\
\hline & $\geq 3$ & $257(24 \%)$ & $464(36 \%)$ & 721 & \\
\hline
\end{tabular}

Keterangan:Yankes = Pelayanan Kesehatan

Tabel 2. Analisis Bivariat Karakteristik Responden dan Penolong Persalinan

\begin{tabular}{|c|c|c|c|c|c|}
\hline \multirow{2}{*}{ Variabel } & \multirow{2}{*}{ Kategori } & \multicolumn{2}{|c|}{ Penolong Persalinan } & \multirow{2}{*}{ Jumlah } & \multirow{2}{*}{ Nilai $p$} \\
\hline & & Nakes & NonNakes & & \\
\hline \multirow[t]{2}{*}{ Umur } & $15-29$ tahun & $761(49 \%)$ & $427(51 \%)$ & 1.188 & \multirow[t]{2}{*}{0,006} \\
\hline & $30-49$ tahun & $791(51 \%)$ & $349(45 \%)$ & 1.140 & \\
\hline \multirow[t]{2}{*}{ Daerah tempat tinggal } & Perkotaan & $767(49 \%)$ & $395(51 \%)$ & 1.162 & \multirow[t]{2}{*}{0,500} \\
\hline & Pedesaan & $785(51 \%)$ & $381(49 \%)$ & 1.166 & \\
\hline \multirow[t]{2}{*}{ Pendidikan } & TS - TT SLTP & $1.058(68 \%)$ & $609(78 \%)$ & 1.667 & \multirow[t]{2}{*}{0,000} \\
\hline & Tamat SLTP ke atas & $493(32 \%)$ & $167(22 \%)$ & 660 & \\
\hline \multirow[t]{2}{*}{ Indeks kesejahteraan } & Termiskin - menengah & $352(23 \%)$ & $225(29 \%)$ & 577 & \multirow[t]{2}{*}{0,001} \\
\hline & Kaya - terkaya & $1.200(77 \%)$ & $552(71 \%)$ & 1.752 & \\
\hline \multirow[t]{2}{*}{ Anak masih hidup } & $0-2$ & $1.071(69 \%)$ & $536(69 \%)$ & 1.607 & \multirow[t]{2}{*}{0,975} \\
\hline & $3+$ & $481(31 \%)$ & $240(31 \%)$ & 721 & \\
\hline
\end{tabular}

Keterangan: Nakes $=$ Tenaga Kesehatan

umur ibu, tingkat pendidikan ibu, dan indeks kesejahteraan dengan pemilihan tenaga penolong persalinan. Persalinan dengan tenaga kesehatan meningkat sesuai dengan peningkatan umur ibu, tingkat pendidikan ibu, dan indeks kesejahteraan. Sementara daerah tempat tinggal dan jumlah anak masih hidup tidak berhubungan secara signifikan dengan penolong persalinan tenaga kesehatan (Lihat Tabel 2).

\section{Karakteristik Ibu dan Penggunaan Kontrasepsi}

Kesertaan dalam program KB meningkat sesuai dengan peningkatan umur ibu. Pada kelompok umur 15 - 19 tahun $49 \%$, umur 20 - 29 tahun $68 \%$, dan sedikit menurun pada umur 30 - 49 tahun (59\%). Penggunaan kontrasepsi pada wanita perkotaan $(63 \%)$ relatif lebih tinggi dibandingkan pedesaan $(60 \%)$. Proporsi penggunaan kontrasepsi semakin meningkat sesuai dengan tingkat pendidikan ibu, wanita yang tidak bersekolah dan SD tidak tamat $(47 \%)$, tamat SD dan SLTP tidak tamat $(62 \%)$, dan SLTP tamat atau lebih tinggi $(70 \%)$. Penggunaan kontrasepsi pada wanita termiskin dan mis- kin menempati urutan terbawah (48\%) diikuti oleh wanita kelas menengah $(63 \%)$ serta kaya dan terkaya $(62 \%)$. Ditemukan hubungan yang signifikan antara kesertaan ber-KB dengan umur ibu, tingkat pendidikan, dan indeks kesejahteraan. Kesertaan ber-KB lebih banyak pada ibu berumur $30-49$ tahun, berpendidikan lebih tinggi, dan indeks kesejahteraan lebih tinggi. Sementara itu, tidak ada hubungan yang signifikan antara kesertaan ber-KB dengan daerah tempat tinggal dan jumlah anak masih hidup (Lihat Tabel 3).

\section{Umur Persalinan}

Sekitar 5,1\% wanita berumur 20 - 49 tahun melahirkan anak pertama tepat pada umur 15 tahun; 20,9\% umur 18 tahun; dan 40,1\% umur 20 tahun. Kelahiran anak pertama pada usia remaja masih cukup tinggi (26\%), yang mengindikasikan kehamilan berisiko tinggi, ditandai dengan penyulit persalinan seperti perdarahan yang berakibat pada kematian ibu dan bayi. Kematian ibu dan bayi masih menjadi masalah di Jawa Barat. Selain itu, dampak psikologis emosi ibu muda yang 
Tabel 3. Karakteristik Sosial Demografi dan Kesertaan dalam Program Keluarga Berencana

\begin{tabular}{|c|c|c|c|c|c|}
\hline \multirow{2}{*}{ Variabel } & \multirow{2}{*}{ Kategori } & \multicolumn{2}{|c|}{ Kesertaan KB } & \multirow{2}{*}{ Jumlah } & \multirow{2}{*}{ Nilai $p$} \\
\hline & & Pakai KB & Tidak KB & & \\
\hline \multirow[t]{2}{*}{ Umur } & $15-29$ tahun & $1.131(35 \%)$ & $581(29 \%)$ & 1.712 & 0,000 \\
\hline & $30-49$ tahun & $2.071(65 \%)$ & $1.460(72 \%)$ & 3.531 & \\
\hline \multirow[t]{2}{*}{ Tempat tinggal } & Perkotaan & $1.601(50 \%)$ & $954(47 \%)$ & 2.555 & 0,021 \\
\hline & Pedesaan & $1.601(50 \%)$ & $1.087(53 \%)$ & 2.688 & \\
\hline \multirow[t]{2}{*}{ Pendidikan } & TS - TT SLTP & $2.351(73 \%)$ & $1.688(82 \%)$ & 4.019 & 0,000 \\
\hline & Tamat SLTP ke atas & $850(27 \%)$ & $374(18 \%)$ & 1.224 & \\
\hline \multirow[t]{2}{*}{ Indeks kesejahteraan } & Termiskin - menengah & $702(22 \%)$ & $523(26 \%)$ & 1.225 & 0,002 \\
\hline & Kaya - terkaya & $2.500(78 \%)$ & $1.518(74 \%)$ & 4.018 & \\
\hline \multirow[t]{2}{*}{ Anak masih hidup } & $0-2$ & $2.140(67 \%)$ & $1.333(65 \%)$ & 3.473 & 0,256 \\
\hline & $\geq 3$ & $1.062(33 \%)$ & $708(35 \%)$ & 1.770 & \\
\hline
\end{tabular}

Tabel 4. Proporsi Persalinan Menurut Umur, Median Usia Persalinan Pertama, dan Umur

\begin{tabular}{|c|c|c|c|c|c|c|c|c|}
\hline \multirow{2}{*}{ Umur Saat Ini } & \multicolumn{6}{|c|}{ Proporsi Persalinan Menurut Umur } & \multirow{2}{*}{ Jumlah } & \multirow{2}{*}{$\begin{array}{c}\text { Median Usia } \\
\text { Persalinan Pertama }\end{array}$} \\
\hline & 15 & 18 & 20 & 22 & 25 & $\begin{array}{l}\text { Tidak pernah } \\
\text { melahirkan }\end{array}$ & & \\
\hline $15-19$ tahun & 0,0 & - & - & - & - & 94,2 & 1.006 & - \\
\hline $20-24$ tahun & 0,4 & 10,3 & 29,7 & - & - & 44,1 & 1.081 & - \\
\hline $25-29$ tahun & 1,8 & 13,0 & 28,2 & 46,9 & 70,7 & 21,4 & 999 & 22,4 \\
\hline $30-34$ tahun & 3,9 & 17,8 & 33,3 & 55,9 & 73,6 & 10,8 & 1.077 & 21,5 \\
\hline $35-39$ tahun & 5,5 & 22,5 & 40,9 & 57,7 & 75,0 & 4,0 & 1.029 & 20,9 \\
\hline $40-44$ tahun & 8,3 & 29,2 & 57,1 & 70,2 & 84,1 & 3,6 & 932 & 19,6 \\
\hline $45-49$ tahun & 13,0 & 37,2 & 56,3 & 72,3 & 85,3 & 1,9 & 832 & 19,4 \\
\hline $20-49$ tahun & 5,1 & 20,9 & 40,1 & - & - & 15,1 & 5.950 & - \\
\hline $25-49$ tahun & 6,2 & 23,3 & 42,4 & 60,0 & 77,3 & 8,7 & 4.870 & 20,8 \\
\hline
\end{tabular}

kurang matang dalam pengasuhan anak berakibat pada kualitas sumber daya manusia yang rendah (Lihat Tabel 4).

\section{Cakupan Antenatal}

Cakupan pemeriksaan kehamilan pada tenaga profesional meningkat sesuai dengan peningkatan jenjang pendidikan ibu dan indeks kekayaan kuintil. Proporsi pemeriksaan kehamilan pada ibu yang tidak sekolah $(71 \%)$ dan ibu yang berpendidikan SD $(80 \%)$ relatif lebih rendah dibandingkan ibu berpendidikan SMTA atau lebih (99\%). Ibu dengan indeks kekayaan kuintil terbawah yang memeriksakan kehamilan pada tenaga profesional $(80 \%)$ lebih sedikit dibandingkan dengan indeks kekayaan kuintil teratas (98\%) (Lihat Tabel 5).

\section{Pemeriksaan Kehamilan}

Pemeriksaan antenatal yang paling sering adalah tinggi fundus (96\%), berat badan (96\%), tekanan darah $(95 \%)$, urin $(39 \%)$, dan tinggi badan (35\%). Sekitar $51 \%$ ibu mendapat penjelasan tentang tanda-tanda komplikasi kehamilan. Penjelasan tersebut umumnya diterima oleh ibu hamil berumur 20 - 30 tahun (53\%), ibu ha- mil pada urutan kelahiran pertama dan keempat atau kelima $(54 \%-55 \%)$, di wilayah perkotaan $(55 \%)$, berpendidikan SMTA atau lebih tinggi $(63 \%)$, dan berada pada indeks kekayaan kuintil menengah atas $(60 \%)$ (Lihat Tabel 6).

\section{Pembahasan}

Tempat dan penolong persalinan berpengaruh terhadap peningkatan kesehatan ibu dan anak. Tempat persalinan yang tidak layak dan penolong persalinan yang tidak terlatih sangat rentan terhadap kematian. Secara keseluruhan, sebanyak $45 \%$ anak dilahirkan di fasilitas kesehatan, fasilitas swasta (39\%), dan fasilitas pemerintah (6\%). Di Jawa Barat, sekitar 68\% kelahiran ditolong oleh tenaga medis, meliputi perawat/bidan di desa $(56 \%)$, dokter spesialis kandungan (11\%), dan dokter umum $(1 \%)$.

Penggunaan alat kontrasepsi pada wanita miskin ditemukan rendah karena beban biaya pelayanan dan transportasi serta kesadaran membatasi kehamilan yang rendah. Studi Pusat Penelitian Kependudukan Lembaga Penelitian dan Pengabdian kepada Masyarakat (LPPM) Universitas Padjadjaran pada tahun 2007 di Kota 
Tabel 5. Distribusi Ibu Menurut Karakteristik dan Tenaga Pemeriksa Kehamilan

\begin{tabular}{|c|c|c|c|c|c|c|c|c|c|}
\hline \multirow{2}{*}{ Variabel } & \multirow{2}{*}{ Kategori } & \multicolumn{7}{|c|}{ Tenaga Pemeriksa Kehamilan (\%) } & \multirow{2}{*}{ Jumlah } \\
\hline & & $\begin{array}{l}\text { Dokter } \\
\text { Umum }\end{array}$ & $\begin{array}{c}\text { Dokter } \\
\text { Kandungan }\end{array}$ & $\begin{array}{c}\text { Perawat/ } \\
\text { Bidan }\end{array}$ & Dukun & $\begin{array}{c}\text { Tenaga } \\
\text { Lain }\end{array}$ & $\begin{array}{l}\text { Tidak } \\
\text { Periksa }\end{array}$ & $\begin{array}{l}\text { Tenaga } \\
\text { Profesi }\end{array}$ & \\
\hline \multirow[t]{3}{*}{ Umur melahirkan } & $<20$ tahun & 2,0 & 4,7 & 87,8 & 0,0 & 2,1 & 3,4 & 94,5 & 245 \\
\hline & $20-34$ tahun & 1,3 & 13,2 & 80,9 & 1,1 & 0,3 & 3,2 & 95,4 & 1.729 \\
\hline & $35-49$ tahun & 2,0 & 7,5 & 85,6 & 2,2 & 0,0 & 2,7 & 95,1 & 353 \\
\hline \multirow[t]{4}{*}{ Urutan kelahiran } & 1 tahun & 2,5 & 13,4 & 80,5 & 0,6 & 0,7 & 2,3 & 96,4 & 849 \\
\hline & $2-3$ tahun & 0,4 & 13,0 & 81,7 & 1,5 & 0,4 & 3,0 & 95,2 & 1.101 \\
\hline & $4-5$ tahun & 0,6 & 2,3 & 93,4 & 2,0 & 0,0 & 1,8 & 96,2 & 290 \\
\hline & $6+$ tahun & 8,1 & 2,9 & 71,0 & 0,0 & 0,0 & 18,0 & 82,0 & 88 \\
\hline \multirow[t]{2}{*}{ Tempat tinggal } & Perkotaan & 1,7 & 17,2 & 79,4 & 0,4 & 0,1 & 1,1 & 98,4 & 1.162 \\
\hline & Pedesaan & 1,3 & 5,7 & 85,2 & 1,9 & 0,8 & 5,1 & 92,2 & 1.166 \\
\hline \multirow[t]{5}{*}{ Pendidikan } & Tidak sekolah & 0,0 & 0,0 & 70,6 & 16,7 & 0,0 & 12,7 & 70,6 & 24 \\
\hline & $<\mathrm{SD}$ & 1,4 & 1,7 & 76,5 & 6,4 & 0,0 & 14,0 & 79,6 & 255 \\
\hline & $\mathrm{SD}$ & 2,4 & 3,4 & 90,2 & 0,8 & 1,1 & 2,1 & 96,0 & 812 \\
\hline & $<$ SMTA & 0,3 & 4,1 & 93,5 & 0,0 & 0,0 & 2,1 & 97,9 & 576 \\
\hline & > SMTA & 1,5 & 32,0 & 65,6 & 0,0 & 0,1 & 0,8 & 99,1 & 660 \\
\hline \multirow[t]{5}{*}{ Kuantil kekayaan } & Terbawah & 2,7 & 3,6 & 71,5 & 9,3 & 0,0 & 12,8 & 77,8 & 236 \\
\hline & Menengah bawah & 1,5 & 2,1 & 92,1 & 0,0 & 0,0 & 4,3 & 95,7 & 340 \\
\hline & Menengah & 1,7 & 4,8 & 89,0 & 0,4 & 0,0 & 4,1 & 95,5 & 476 \\
\hline & Menengah atas & 1,6 & 5,6 & 91,2 & 0,0 & 1,6 & 0,0 & 98,4 & 593 \\
\hline & Teratas & 0,9 & 28,4 & 68,8 & 0,5 & 0,1 & 1,2 & 98,2 & 683 \\
\hline Jumlah & & 1,5 & 11,4 & 82,3 & 1,2 & 0,4 & 3,1 & 95,3 & 2.328 \\
\hline
\end{tabular}

Bandung menemukan bahwa pengetahuan keluarga miskin terhadap program KB termasuk rendah $(<30 \%)$ sehingga berdampak pada penggunaan alat kontrasepsi yang rendah. ${ }^{3}$ Hal ini dapat juga dipengaruhi oleh berkurangnya jumlah petugas $\mathrm{KB}$ dalam memberikan komunikasi, informasi, dan edukasi kepada masyarakat dari tahun 2001 hingga 2007. ${ }^{7}$ Wanita berumur muda (15 19 tahun) yang tidak menggunakan kontrasepsi sebesar $50,9 \%$, sisanya menggunakan kontrasepsi pil dan suntik. Wanita berumur 20 - 29 tahun dan 30 - 49 tahun umumnya menggunakan alat kontrasepsi berbeda dengan wanita berumur $15-19$ tahun dan $20-49$ tahun yang mayoritas menggunakan metode suntik pil dan intrauterine device (IUD).

Pengguna alat kontrasepsi di perkotaan $(63 \%)$ lebih tinggi dibandingkan pedesaan $(60 \%)$, penggunaan kontrasepsi modern di perkotaan $(62 \%)$ juga lebih tinggi dibandingkan pedesaan (59\%). Wanita perkotaan lebih banyak yang menggunakan IUD, kondom, dan sterilisasi wanita, sementara wanita pedesaan lebih memilih menggunakan pil, suntik, dan susuk KB. Sekitar $46 \%$ wanita kawin yang tidak sekolah menggunakan alat/cara KB modern dan sekitar $68 \%$ wanita yang berpendidikan SMTA atau lebih tinggi menggunakan alat kontrasepsi. Semakin tinggi pendidikan wanita, semakin tinggi keikutsertaan dalam penggunaan alat kontrasepsi. ${ }^{6}$ Program KB yang efektif berpengaruh lebih besar pada fertilitas kelompok sosial ekonomi tinggi yang kemudian berpengaruh pada keputusan penggunaan alat kontrasepsi. Peningkatan pe- serta KB sesuai dengan peningkatan indeks kekayaan. Wanita kelompok kuintil terbawah yang menggunakan alat kontrasepsi modern (48\%) lebih rendah dibandingkan wanita dengan indeks kekayaan kuintil teratas $(62 \%)$. Penggunaan alat kontrasepsi modern oleh masyarakat hingga kini mengindikasikan pengetahuan tentang metode KB modern di kalangan ibu tergolong baik.

Jumlah anak berhubungan secara bermakna dengan penggunaan kontrasepsi modern, ibu yang mempunyai anak banyak cenderung menggunakan alat kontrasepsi. Penggunaan alat kontrasepsi pada wanita dengan jumlah anak 3 - $4(65 \%)$ cenderung menurun jauh setelah jumlah anak 5 atau lebih (39\%). Penggunaan pil atau suntik pada kelompok ibu yang belum mempunyai anak (12\% dan $4 \%$ ) dan penggunaan suntik mengalami peningkatan yang tajam setelah kelahiran anak pertama dan kedua. Ibu dengan jumlah anak 3 atau lebih secara psikologis merasa cukup dan memutuskan untuk melakukan strerilisasi.

Determinan fertilitas meliputi faktor demografi seperti umur kawin pertama dan faktor nondemografi antara lain kondisi ekonomi dan tingkat pendidikan. Faktor sosial berpengaruh berhadap fertilitas melalui 11 variabel antara lain umur kawin pertama. ${ }^{8}$ Median umur kawin pertama di Jawa Barat (18,9 tahun) relatif lebih kecil dari Indonesia (19,2 tahun). Secara umum, tingkat pendidikan dan indeks kekayaan berhubungan positif dengan semua komponen pemeriksaan kehamilan. Semakin tinggi jenjang pendidikan ibu dan semakin 
Tabel 6. Ibu yang Memeriksa Kehamilan dan Mendapat Pil Zat Besi

\begin{tabular}{|c|c|c|c|c|c|c|c|c|c|c|}
\hline \multirow{2}{*}{ Variabel } & \multirow{2}{*}{ Kategori } & \multirow{2}{*}{$\begin{array}{l}\text { Komplikasi } \\
\text { Kehamilan }\end{array}$} & \multicolumn{6}{|c|}{ Pemeriksaan } & \multirow{2}{*}{ Pil Besi } & \multirow{2}{*}{ Jumlah } \\
\hline & & & $\begin{array}{c}\text { Berat } \\
\text { Badan }\end{array}$ & $\begin{array}{l}\text { Tinggi } \\
\text { Badan }\end{array}$ & $\begin{array}{l}\text { Tekanan } \\
\text { Darah }\end{array}$ & Urin & Darah & Perut & & \\
\hline \multirow[t]{3}{*}{ Umur melahirkan } & $<20$ tahun & 31,8 & 89,8 & 28,1 & 87,3 & 31,8 & 13,7 & 95,5 & 74,0 & 245 \\
\hline & $20-34$ tahun & 53,4 & 96,8 & 36,9 & 96,1 & 42,3 & 30,1 & 97,1 & 84,8 & 1.729 \\
\hline & $35-49$ tahun & 51,2 & 94,3 & 28,3 & 94,4 & 26,7 & 26,4 & 92,5 & 74,6 & 353 \\
\hline \multirow[t]{4}{*}{ Urutan kelahiran } & 1 & 54,7 & 94,9 & 39,6 & 95,6 & 44,6 & 27,7 & 96,5 & 82,9 & 849 \\
\hline & $2-3$ & 48,0 & 96,6 & 32,9 & 95,0 & 38,5 & 29,1 & 97,1 & 86,2 & 1.101 \\
\hline & $4-5$ & 54,4 & 98,0 & 28,2 & 96,9 & 29,7 & 25,2 & 93,6 & 74,8 & 290 \\
\hline & $6+$ & 32,4 & 83,3 & 29,2 & 77,9 & 13,8 & 20,7 & 90,2 & 46,7 & 88 \\
\hline \multirow[t]{2}{*}{ Tempat tinggal } & Perkotaan & 55,2 & 98,6 & 36,3 & 97,1 & 45,7 & 30,1 & 97,3 & 87,3 & 1.162 \\
\hline & Pedesaan & 46,3 & 92,7 & 32,9 & 92,6 & 31,8 & 25,5 & 95,0 & 76,9 & 1.166 \\
\hline \multirow[t]{5}{*}{ Pendidikan } & Tidak sekolah & 8,6 & 66,7 & 27,7 & 50,5 & 0,0 & 11,4 & 85,9 & 34,1 & 24 \\
\hline & $\leq \mathrm{SD}$ & 20,2 & 81,9 & 31,6 & 79,3 & 21,6 & 34,6 & 93,1 & 62,7 & 255 \\
\hline & $\overline{\mathrm{SMTP}}$ & 45,2 & 94,3 & 26,5 & 92,7 & 34,5 & 25,6 & 96,4 & 76,9 & 812 \\
\hline & $<$ SMTA & 57,7 & 99,1 & 34,2 & 100,0 & 41,1 & 23,6 & 97,3 & 87,8 & 576 \\
\hline & $\leq$ SMTA & 63,3 & 100,0 & 46,1 & 99,9 & 49,2 & 32,5 & 96,4 & 92,7 & 660 \\
\hline \multirow[t]{5}{*}{ Indeks kekayaan } & Terbawah & 28,0 & 76,9 & 25,0 & 77,8 & 21,3 & 25,3 & 88,4 & 61,3 & 236 \\
\hline & Menengah bawah & 35,9 & 94,8 & 27,0 & 92,9 & 24,6 & 21,4 & 97,9 & 78,7 & 340 \\
\hline & Menengah & 47,8 & 96,5 & 36,6 & 95,3 & 33,7 & 26,8 & 98,1 & 80,6 & 476 \\
\hline & Menengah atas & 59,8 & 97,8 & 33,0 & 96,8 & 39,9 & 26,6 & 96,5 & 86,5 & 593 \\
\hline & Teratas & 59,1 & 99,5 & 41,4 & 99,2 & 53,6 & 33,5 & 96,2 & 88,2 & 683 \\
\hline Jumlah & & 50,8 & 95,7 & 34,6 & 94,9 & 38,8 & 27,8 & 96,2 & 82,1 & 2.328 \\
\hline
\end{tabular}

tinggi status indeks kekayaan kuintil, semakin besar kemungkinan memeriksakan semua komponen pemeriksaan kehamilan.

Selama kehamilan, para ibu dianjurkan meminum paling sedikit 90 pil zat besi. ${ }^{1}$ Penelitian memperlihatkan bahwa $82 \%$ ibu hamil di Jawa Barat yang meminum pil zat besi berhubungan negatif dengan urutan kelahiran, tetapi berhubungan positif dengan tingkat pendidikan dan indeks kekayaan ibu. Proporsi ibu di perkotaan yang mendapatkan pil zat besi selama kehamilan terakhir $(87 \%)$ jauh lebih tinggi dibandingkan ibu yang tinggal di pedesaan $(77 \%)$.

\section{Kesimpulan}

Persalinan di fasilitas kesehatan lebih banyak dilakukan oleh ibu dengan umur persalinan pertama 20 tahun atau lebih, pada kelahiran pertama, dan yang bermukim di perkotaan. Sekitar 74\% kelahiran anak pertama ditolong oleh penolong profesional, semakin menurun pada ibu yang tidak ditolong tenaga profesional, dan semakin menurun dengan peningkatan urutan kelahiran. Satu dari tiga persalinan ditolong oleh dukun bayi yang masih berperan dominan membantu persalinan, terutama pada wanita berumur kurang dari 20 tahun, berpendidikan rendah, berasal dari kelompok ekonomi rendah serta bermukim di pedesaan. Persalinan bedah caesar lebih banyak terjadi pada ibu berumur 35 - 49 tahun, pada urutan kelahiran pertama, pendidikan lebih tinggi, kekayaan kuintil teratas, dan di daerah perkotaan. Terdapat hubungan yang signifikan antara kesertaan dalam program KB dengan umur ibu, tingkat pendidikan, dan indeks kesejahteraan. Kesertaan ber-KB meningkat bersamaan dengan peningkatan umur wanita dan penggunaan kontrasepsi pada wanita perkotaan lebih tinggi dibandingkan pedesaan. Penggunaan kontrasepsi modern mengalami peningkatan pesat pada kelompok ibu yang mempunyai 1 dan 2 anak, tetapi sedikit menurun pada wanita dengan 3 atau 4 anak. Penurunan terjadi sangat nyata setelah mempunyai 3 - 5 anak atau lebih.

\section{Saran}

Perlu dikembangkan kebijakan yang meningkatkan cakupan tenaga profesional penolong persalinan pada ibu berisiko tinggi, tinggal di pedesaan, tingkat pendidikan rendah, dan indeks kekayaan terendah. Untuk meningkatkan proporsi pengguna kontrasepsi perlu dirumuskan program yang berpihak kepada wanita, di pedesaan dan perkotaan, berpendidikan rendah, kelompok umur muda, indeks kekayaan termiskin serta tertinggi. Perlu diteruskan pola penggarapan daerah tertinggal, terpencil, dan perbatasan melalui penggarapan khusus.

\section{Daftar Pustaka}

1. Kementerian Kesehatan Republik Indonesia. National strategic plan for 
making pregnancy safer (MPS) in Indonesia 2001-2010. Jakarta: Kementerian Kesehatan Republik Indonesia; 2001.

2. Badan Pusat Statistik dan ORC Macro. Survei demografi dan kesehatan Indonesia 2007. Calverton, Maryland, United States of America: adan Pusat Statistik dan ORC Macro; 2007.

3. Pusat Penelitian dan Pengembangan Keluarga Berencana dan Kesehatan Reproduksi Badan Kependudukan dan Keluarga Berencana Nasional. Survei demografi dan kesehatan Indonesia 2007 Provinsi Jawa Barat. Jakarta: Pusat Penelitian dan Pengembangan Keluarga Berencana dan Kesehatan Reproduksi Badan Kependudukan dan Keluarga Berencana Nasional; 2009.

4. Omas BS. Analisis dan interpretasi data SDKI 2007. Jakarta: Lembaga
Demografi Fakultas Ekonomi Universitas Indonesia; 2009.

5. Lembaga Demografi Fakultas Ekonomi Universitas Indonesia. Warta Demografi. 2004; 34 (2).

6. Soeradji, Budi, Sri HH, Ananta. 1987. Analisis determinan pemakaian kontrasepsi dan efisiensi pelaksanaan program keluarga berencana. Jakarta: Akademi Ilmu Statistik, Biro Statistik, dan Lembaga Demografi Fakultas Ekonomi Universitas Indonesia; 1987.

7. Kurniawan UK, Pratomo H, Bachtiar A. Kinerja penyuluhan keluarga berencana di Indonesia: pedoman pengujian efektivitas kinerja pada era desentralisasi. Kesmas, Jurnal Kesehatan Masyarakat Nasional. 2010; 5 (1): 3-8.

8. Mantra IB. Demografi umum. Yogyakarta: Pustaka Pelajar; 2000. 